\title{
Left Main Coronary Artery Body
}

National Cancer Institute

\section{Source}

National Cancer Institute. Left Main Coronary Artery Body. NCI Thesaurus. Code C116173.

The segment of the left main coronary artery that is bounded by its ostium and bifurcation. 